Article

\title{
In-Situ pH-Sensitive Fibers via the Anchoring of Bromothymol Blue on Cellulose Grafted with Hydroxypropyltriethylamine Groups via Adsorption
}

\author{
Lele Cao ${ }^{1,2}$, Tieqiang Liang ${ }^{1,2}$, Xipeng Zhang ${ }^{3}$, Wenbo Liu ${ }^{1}$, Jian $\mathrm{Li}^{1,2}{ }^{1}$, Xianxu Zhan ${ }^{4}$ and \\ Lijuan Wang 1,2,* \\ 1 Key Laboratory of Bio-Based Materials Science and Technology of ministry of Education, Northeast Forestry \\ University, Harbin 150040, China; 18846170635@163.com (L.C.); ltq@nefu.edu.cn (T.L.); \\ hljwbo@nefu.edu.cn (W.L.); nefulijian@163.com (J.L.) \\ 2 Research Center of Wood Bionic Intelligent Science, Northeast Forestry University, Harbin 150040, China \\ 3 School of Environment, Harbin institute of Technology, Harbin 150040, China; 96315zh@163.com \\ 4 Dehua TB New Decoration Material CO., LTD, Deqing 313200, China; zhanxianxu@126.com \\ * Correspondence: donglinwlj@163.com; Tel.: +86-451-82191693
}

Received: 21 May 2018; Accepted: 26 June 2018; Published: 27 June 2018

\begin{abstract}
In-situ pH-sensitive cellulose fibers (IS-pH-SCF) were prepared by anchoring bromothymol blue (BTB) onto cellulose fibers (CF) modified with hydroxypropyltriethylamine (HPTTL) groups. Fourier transform infrared and X-ray photoelectron spectrum analyses demonstrated that the HPTTL groups were grafted onto the CF. X-ray diffraction proved that cellulose I in the CF transformed into cellulose II after quaternization. Scanning electron microscopy suggested that the quaternized CF (QCF) surface was clean and uniformly ridged. The adsorption of BTB onto QCF was carried out via batch adsorption experiments. A kinetic study illustrated that the adsorption was a spontaneous process and described well by pseudo-second-order, Freundlich and Temkin isotherms. The activation energy for the BTB adsorption onto QCF was $52.89 \mathrm{~kJ} / \mathrm{mol}$, which proved that the BTB adsorption onto QCFs was chemically controlled. The $\mathrm{pH}$ response demonstrated that the IS-pH-SCF was highly sensitive to $\mathrm{pH}$, with an obvious color change for $\mathrm{pH} 4$ to 8 . The release tests showed that BTB was anchored on QCFs and that no BTB was released. IS-pH-SCF has a potential use for indicating $\mathrm{pH}$ changes in food.
\end{abstract}

Keywords: cellulose fiber; cationic modification; anchoring; bromothymol blue; in-situ pH-sensitive

\section{Introduction}

Foods are rich in nutrients and are the most basic materials for human survival. Food safety is directly related to human physical health and life safety, and is critical to ensure both economic and social stability. Food quality deteriorates because of moisture, light, microbial reproduction during transportation, and storage. Food spoilage could lead to a reduction or loss of nutritional value and even cause food poisoning, with a potential for great harm and significant economic losses. Improvements in living standards have resulted in people paying increased attention to food safety. The traditional food quality test is based on a chemical analysis, which requires the destruction of foods, expensive analytical instruments, professional operators, and extended times [1]. Such analyses are not always feasible because the detection is not readily accessible by the public. To overcome these disadvantages, intelligent packaging materials and indicators have been favored by scholars for the real-time detection of food quality [2]. In general, the spoilage of foods may be accompanied by $\mathrm{pH}$ changes. For example, protein-rich foods (fish and pork, for example) release organic amines during the spoilage, which results in an increase in $\mathrm{pH}$ [3]. Polysaccharide-rich foods release carbon dioxide and 
other acidic gases, which leads to a reduction in $\mathrm{pH}$. In recent years, $\mathrm{pH}$-sensitive sensors [4-10] and $\mathrm{pH}$-sensitive packaging films [11-14] have been reported. Synthetic dyes are highly sensitive and have obvious color changes for tiny $\mathrm{pH}$ changes, and this phenomenon has been used by many researchers. A pH dye-based indicator, prepared by coating a mixed solution of bromothymol blue and methyl red on a film that was prepared with nylon with linear low-density polyethylene, was applied to monitor a golden drop (a premium dessert produced in Thailand), and proved that it can serve as a real-time indicator for spoilage via color changes [15]. Lee [3] prepared a gas-freshness indicator composed of bromothymol blue-phenol red, which was used to indicate the freshness of fish by obvious color changes based on the quantity of volatile amines. Although synthetic dyes are much more sensitive to $\mathrm{pH}$ changes, their inedibility makes them potentially harmful for human health when they migrate from the matrices to food. Therefore, researchers have focused on natural pigments extracted from fruits or vegetables [16-18] to prepare $\mathrm{pH}$ indicators or $\mathrm{pH}$ sensitive packaging materials [19-21]. Chen reported that a $\mathrm{pH}$ sensitive fabric dyed by using turmeric showed a significant color change when the $\mathrm{pH}$ changed from neutral to alkaline [22]; however, no obvious color change resulted when the $\mathrm{pH}$ changed from neutral to acidic. Ma [19] prepared an intelligent packaging film by incorporating anthocyanins that were extracted from mulberry to monitor the putrefaction of fish. The color changed to green when the fish was putrid. However, the color change was not sensitive or not sufficiently accurate to indicate the inflection point from freshness to slight spoilage of the fish. As a result of their chemical structures, natural pigments are not accurately sensitive to slight $\mathrm{pH}$ changes. To obtain highly $\mathrm{pH}$-sensitive fibers, $\mathrm{pH}$ sensitive synthetic dyes are required and migration must be prevented via firm interactions. To our knowledge, no report exists on in-situ $\mathrm{pH}$-sensitive cellulose fibers ( $\mathrm{CFs})$ via the anchoring of $\mathrm{pH}$-sensitive synthetic dyes.

Bromothymol blue (BTB) is a pH-sensitive synthetic dye that is used extensively in indicators [23-25]. As shown in Figure 1, it is negatively charged in alkaline solution. Cellulose fiber (CF) is a rich, renewable, biodegradable and non-toxic material composed of a linear chain of $\beta$-(1 $\rightarrow 4)$-linked D-glucopyranosyl units [26]. CF is insoluble in water and any other common organic solvents [27]. It is a favorite carrier to anchor $\mathrm{pH}$-sensitive synthetic dyes. However, $\mathrm{OH}$-rich $\mathrm{CF}$ cannot anchor BTB because the interactions between the molecules are too weak. Therefore, a cationic modification is necessary for CF to anchor BTB in alkaline conditions through electrostatic attraction.<smiles>CC1=C(Br)C(=O)C(C(C)C)=CC1=C(c1ccccc1S(=O)(=O)c1cc(C(C)C)c([O-])c(Br)c1C)c1cc(C2(c3cc(C(C)C)c(O)c(Br)c3C)OS(=O)(=O)c3ccccc32)c(C)c(Br)c1O</smiles>

Figure 1. Structural changes of bromothymol blue in acid and alkaline solutions.

In this study, CFs were positively charged via a cationic modification in which quaternary ammonium groups were grafted onto cellulose molecules. In-situ pH-sensitive CFs (IS-pH-SCF) were prepared by anchoring BTB onto quaternized CFs (QCF) in a $\mathrm{NaOH}$ solution. The QCF and IS-pH-SCF were analyzed by Fourier transform infrared (FTIR) spectroscopy, X-ray photoelectron spectroscopy (XPS), X-ray diffraction (XRD), and scanning electron microscopy (SEM). QCF was tested as an adsorbent for BTB from a NaOH solution. The effects of the QCF dosage and contact time were 
investigated. The kinetics and isotherms of the adsorption process were studied. The $\mathrm{pH}$-sensitivity of the IS-pH-SCF and the non-release of BTB were measured.

\section{Materials and Methods}

\subsection{Materials}

Bleached softwood kraft pulp was used as a cellulose fiber (CF) and offered by Henfeng Paper Co., Ltd. (Mudanjiang, China). Bromothymol blue (BTB) was supplied by the Guangfu Chemical Research Institute (Tianjin, China). All other chemicals, including sodium hydroxide, epoxy chloropropane, triethylamine, hydrochloric acid, absolute ethyl alcohol and buffer solutions ( $\mathrm{pH} 4$ to 8), were supplied by Yongda Chemical Reagent Co., Ltd. (Tianjin, China). All chemicals were of analytical grade and used without purification.

\subsection{Preparation and Characterization of Quaternized Cellulose Fiber (QCF)}

\subsubsection{Preparation of the QCF}

QCF was prepared according to the literature with slight modifications [28]. The CF was ground to a powder with a size of $125 \sim 180 \mu \mathrm{m}$. The CF powder $(5 \mathrm{~g})$ and $125 \mathrm{~mL}$ of a $\mathrm{NaOH}$ solution $(20 \% w / w)$ were stirred at $500 \mathrm{rpm}$ and $25{ }^{\circ} \mathrm{C}$ for $2 \mathrm{~h}$. A NaOH solution $(125 \mathrm{~mL}, 10 \% \mathrm{w} / \mathrm{w})$ and $60 \mathrm{~mL}$ of epoxy chloropropane were added into the flask after the solution had been removed by filtration. The mixture was heated to $65^{\circ} \mathrm{C}$ and stirred at $500 \mathrm{rpm}$ for $7 \mathrm{~h} .70 \mathrm{~mL}$ of triethylamine/absolute ethyl alcohol solution $(34 \% v / v)$ was added into the flask after a solid-liquid separation, and the mixture was stirred at $500 \mathrm{rpm}$ and $75^{\circ} \mathrm{C}$ for $4 \mathrm{~h}$. Absolute ethanol was used to wash the resulting product to remove the unreacted triethylamine. Then, the product was washed successively with $0.1 \mathrm{M} \mathrm{NaOH}, 0.1 \mathrm{M} \mathrm{HCl}$ and distilled water until it reached a pH of 7 . The QCF was dried at $65^{\circ} \mathrm{C}$ for $10 \mathrm{~h}$.

\subsubsection{Characterization of the QCF}

The FTIR spectra of the CF and the QCF were measured by using a Nicolet 6700 spectrometer (ThermoFischer, Waltham, MA, USA), and tests were conducted from 500 to $4000 \mathrm{~cm}^{-1}$ with a resolution of $4 \mathrm{~cm}^{-1}$. An XPS analyzer with K-Alpha (Thermo, VGS, Waltham, MA, USA) was employed to detect the X-ray photoelectron spectroscopy. The XRD patterns of the CF and the QCF were acquired by using a D/MAX-2500 diffractometer (Cu-K $\alpha$ target, $40 \mathrm{kV}, 30 \mathrm{~mA}$ ) at $1200 \mathrm{~W}$ (Rigaku, Tokyo, Japan). A Hitachi SU-70 microscope (Hitachi, Ibaraki, Japan) was employed to analyze the surface morphology of the CF and the QCF. A thin layer of gold was deposited on the surface of the samples before the observation.

\subsection{Adsorption Experiments}

The adsorption of BTB on the QCF in the dilute alkaline solution $(0.1 \mathrm{M} \mathrm{NaOH})$ and the effects of both the QCF dosage and the adsorption time on the adsorption were investigated by batch adsorption experiments. The standard curve of BTB in a $0.1 \mathrm{M} \mathrm{NaOH}$ solution was obtained by using an ultraviolet-visible spectrophotometer (UV-2600, Shimadzu, Kyoto, Japan). For each adsorption experiment, $50 \mathrm{~mL}$ of $\mathrm{BTB} / \mathrm{NaOH}$ solution with $1000 \mathrm{mg} / \mathrm{L}$ and a certain amount of QCF were added into a beaker under magnetic stirring of $200 \mathrm{rpm}$ for different times until the adsorption reached an equilibrium. The mixture was separated by using a benchtop high-speed centrifuge (TG16-WS, Changsha, China) at 10,000 r/min for $6 \mathrm{~min}$. Subsequently, the residual BTB/ $\mathrm{NaOH}$ solution was diluted 50 times with a $0.1 \mathrm{M} \mathrm{NaOH}$ solution, and then the absorbance was measured with the ultraviolet-visible spectrophotometer at $615 \mathrm{~nm}$. The concentration of BTB was calculated according 
to the standard curve. The adsorption capacity at time $\mathrm{t}\left(\mathrm{q}_{\mathrm{t}}, \mathrm{mg} / \mathrm{g}\right)$ and the equilibrium $\left(\mathrm{q}_{\mathrm{e}}, \mathrm{mg} / \mathrm{g}\right)$ are obtained from the following equations:

$$
\begin{aligned}
& \mathrm{q}_{\mathrm{e}}=\left[\left(\mathrm{C}_{0}-\mathrm{C}_{\mathrm{e}}\right) / \mathrm{m}\right] \times \mathrm{V} \\
& \mathrm{q}_{\mathrm{t}}=\left[\left(\mathrm{C}_{0}-\mathrm{C}_{\mathrm{t}}\right) / \mathrm{m}\right] \times \mathrm{V}
\end{aligned}
$$

where $\mathrm{C}_{0}, \mathrm{C}_{\mathrm{e}}$ and $\mathrm{C}_{\mathrm{t}}(\mathrm{mg} / \mathrm{L})$ denote the concentration of the $\mathrm{BTB} / \mathrm{NaOH}$ solution at initial, equilibrium and $\mathrm{t}(\mathrm{min})$, respectively. $\mathrm{V}(\mathrm{L})$ represents the volume of $\mathrm{BTB} / \mathrm{NaOH}$ solution and $\mathrm{m}(\mathrm{g})$ presents the QCF dosage.

\subsection{Adsorption Kinetics and Isotherms}

\subsubsection{Kinetic Models}

The adsorption experiments were performed by magnetically stirring $100 \mathrm{mg}$ of QCF and $50 \mathrm{~mL}$ of $\mathrm{BTB} / \mathrm{NaOH}$ solution with $1000 \mathrm{mg} / \mathrm{L}$ at $200 \mathrm{rpm}$ for different time intervals at various temperatures to explore the kinetics. The adsorption process was analyzed via pseudo-first-order and pseudo-second-order models [29]. In general, the pseudo-first-order is used to elaborate the initial stage of the adsorption process and can be shown as:

$$
\ln \left(\mathrm{q}_{\mathrm{e}}-\mathrm{q}_{\mathrm{t}}\right)=\ln \mathrm{q}_{\mathrm{e} 1}-\mathrm{K}_{1} \mathrm{t}
$$

where $\mathrm{q}_{\mathrm{e}}$ and $\mathrm{q}_{\mathrm{t}}(\mathrm{mg} / \mathrm{g})$ indicate the quality of BTB adsorbed onto the QCF at equilibrium and $\mathrm{t}$ $(\mathrm{min})$, respectively. The $\mathrm{q}_{\mathrm{e} 1}(\mathrm{mg} / \mathrm{g})$ denotes the theoretical value of $\mathrm{BTB}$ adsorbed onto the QCF at equilibrium, and $\mathrm{K}_{1}(1 / \mathrm{min})$ represents the rate constant.

The pseudo-second-order model describes the whole process of the adsorption and conforms to the mechanism of chemical adsorption [30]. The model can be matched by the following equation:

$$
t / q_{t}=1 /\left(K_{2} q_{e}{ }^{2}\right)+t / q_{e} 2
$$

where $\mathrm{q}_{\mathrm{e} 2}(\mathrm{mg} / \mathrm{g})$ denotes the theoretical quality of BTB adsorbed onto the adsorbent at equilibrium, and $\mathrm{q}_{\mathrm{t}}(\mathrm{mg} / \mathrm{g})$ is denotes the theoretical quality of BTB adsorbed onto the adsorbent at time $\mathrm{t}(\mathrm{min})$. The $\mathrm{K}_{2}$ (g/mg min) represents the rate constant.

The activation energy Ea [31] of the adsorption can be calculated by using the following equation:

$$
\ln \mathrm{K}_{2}=\ln \mathrm{A}-\mathrm{Ea} /(\mathrm{RT})
$$

where A represents the Arrhenius factor.

\subsubsection{Isotherm Models}

$50 \mathrm{~mL}$ of a BTB/ $\mathrm{NaOH}$ solution with $1000 \mathrm{mg} / \mathrm{L}$ and a certain quality $(100,200,300,400$, 500 , or $600 \mathrm{mg}$ ) of QCF were stirred in a magnetic stirring water bath at $200 \mathrm{rpm}$ for $4 \mathrm{~h} \mathrm{at}$ different temperatures $(303.15,313.15$, or $323.15 \mathrm{~K})$ to study the adsorption isotherm. Langmuir [32], Freundlich [33] and Temkin [34] isotherms were applied to analyze the experiment data and to help understand the adsorption process. The adsorption isotherm models can be represented as:

$$
\begin{gathered}
C_{e} / q_{e}=1 /\left(K_{L} q_{m}\right)+C_{e} / q_{m} \\
q_{e}=K_{f} \times C_{e}^{1 / n} \\
q_{e}=A+B \times \ln C_{e}
\end{gathered}
$$


where $\mathrm{q}_{\mathrm{m}}(\mathrm{mg} / \mathrm{g})$ is the maximum adsorption capacity, $\mathrm{q}_{\mathrm{e}}(\mathrm{mg} / \mathrm{g})$ is the equilibrium adsorption capacity, $\mathrm{C}_{\mathrm{e}}(\mathrm{mg} / \mathrm{L})$ represents the concentration of the $\mathrm{BTB} / \mathrm{NaOH}$ solution at equilibrium, and $\mathrm{K}_{\mathrm{L}}$ $(\mathrm{L} / \mathrm{mg})$ denotes the Langmuir adsorption constant. $\mathrm{K}_{\mathrm{f}}$ denotes the Freundlich constant and $\mathrm{n}$ denotes the heterogeneity factor. A and B are the Temkin dasorption isothermal constants [35].

\subsection{Preparation and Characterization of In-Situ pH-Sensitive Cellulose Fibers (IS-pH-SCF)}

\subsubsection{Preparation of IS-pH-SCF}

The QCF (2 g) and $200 \mathrm{~mL}$ of a BTB/NaOH solution (1000 mg/L) were added into a beaker and stirred in a magnetic stirring water bath at $200 \mathrm{rpm}$ for $4 \mathrm{~h}$ at $50{ }^{\circ} \mathrm{C}$. The mixture was separated via filtration with a 200 mesh filter cloth. The isolated solids were soaked in distilled water and stirred at $\sim 500 \mathrm{rpm}$ for $5 \mathrm{~min}$, followed by a vacuum filtration, and this was repeated 5 times until the filtrate was colorless and neutral. $0.1 \mathrm{~g}$ of IS-pH-SCFs and distilled water $(50 \mathrm{~mL})$ were stirred at $500 \mathrm{rpm}$ to disperse the IS-pH-SCFs uniformly. Following this, the suspension was added slowly into the Buchner funnel equipped with two layers of filter paper and vacuum filtration was performed at $0.08 \mathrm{MPa}$. Circular IS-pH-SCF felts were obtained and dried at $65^{\circ} \mathrm{C}$.

\subsubsection{Characterization of IS-pH-SCF}

The FTIR analysis and SEM observation of IS-pH-SCF were conducted by using the same methods as those for QCF.

\section{6. $p H$ Response of IS- $p H-S C F$}

The circular pieces of IS-pH-SCF felts were cut into rectangles $(2 \mathrm{~cm} \times 2 \mathrm{~cm})$. Individual buffered solutions ( $5 \mathrm{~mL}, \mathrm{pH}=4,5,6,7$, and 8 ) were placed in glass culture dishes (marked 4 to 8). The IS-pH-SCF felt was soaked in a buffer solution for $30 \mathrm{~s}$, then removed with tweezers and placed on several layers of filter paper. A portable colorimeter (Xrite2600d, X-rite, Grand Rapids, MI, USA) was employed to analyze the color of the IS-pH-SCF rectangles, including L (luminosity), a (carmine-green) and $\mathrm{b}$ (yellow-blue). Five detections were performed for each IS-pH-SCF. The total chromatic difference $(\Delta \mathrm{E})$ was obtained as:

$$
\Delta \mathrm{E}=\sqrt{\left(\mathrm{L}-\mathrm{L}_{0}\right)^{2}+\left(\mathrm{a}-\mathrm{a}_{0}\right)^{2}+\left(\mathrm{b}-\mathrm{b}_{0}\right)^{2}}
$$

where $\mathrm{L}_{0}$, $\mathrm{a}_{0}$ and $\mathrm{b}_{0}$ are chromatic values of the IS-pH-SCF. $\mathrm{L}$, and $\mathrm{a}$ and $\mathrm{b}$ are chromatic parameters of the IS-pH-SCF at different $\mathrm{pH}$ values.

\subsection{Release of BTB from IS- $p H-S C F$}

A piece of the IS-pH-SCF was soaked in distilled water $(\mathrm{pH}=7)$ for $24 \mathrm{~h}$, before the IS-pH-SCF was taken out with a pair of tweezers. Subsequently, the color of the resulting distilled water was observed after the very small fibers were separated by centrifugation. An $\mathrm{HCl}$ solution $(0.1 \mathrm{M})$ was dropped on an IS-pH-SCF felt on a piece of filter paper, and the color change of the IS-pH-SCF was observed. After $5 \mathrm{~min}$, the IS-pH-SCF was removed and the color of the original location where IS-pH-SCF had been was observed before and after drying. In addition, the experiments were also conducted by using a $\mathrm{NaOH}$ solution $(0.1 \mathrm{M})$.

\section{Results and Discussion}

\subsection{Analyses of the QCF}

Figure 2A shows the FTIR spectra of the CF and the QCF. The band from 3695 to $2978 \mathrm{~cm}^{-1}$ is the $\mathrm{O}-\mathrm{H}$ stretching vibration, and the band at $\sim 2906 \mathrm{~cm}^{-1}$ corresponds to the $\mathrm{C}-\mathrm{H}$ stretching of the $-\mathrm{CH}_{2}-$ groups. The bands at $\sim 1158,1098,1057$, and $1030 \mathrm{~cm}^{-1}$ originated from the $\mathrm{C}-\mathrm{O}-\mathrm{C}$ 
stretching from the glycosidic bonds of the cellulose molecule [36]. After quaternization, the O-H stretching band weakened and moved to a high wavenumber, and a new band occurred at 1460 $\mathrm{cm}^{-1}$, corresponding to the $\mathrm{C}-\mathrm{N}$ stretching vibration of $-\mathrm{N}^{+}\left(\mathrm{C}_{2} \mathrm{H}_{5}\right)_{3}$ [37]. The changes showed that the $-\mathrm{N}^{+}\left(\mathrm{C}_{2} \mathrm{H}_{5}\right)_{3}$ has been grafted onto the cellulose skeleton. In the XPS spectrum (Figure 2B), peaks at 398.81 and $401.26 \mathrm{eV}$ showed that nitrogen was present in the QCF in ternary and quaternary states [38,39], respectively. The former is likely to be an admixture of trimethylamine in the QCF preparation. The total nitrogen content of the QCF was 1.73\% from the XPS analysis. The XPS results further confirmed the FTIR analysis.
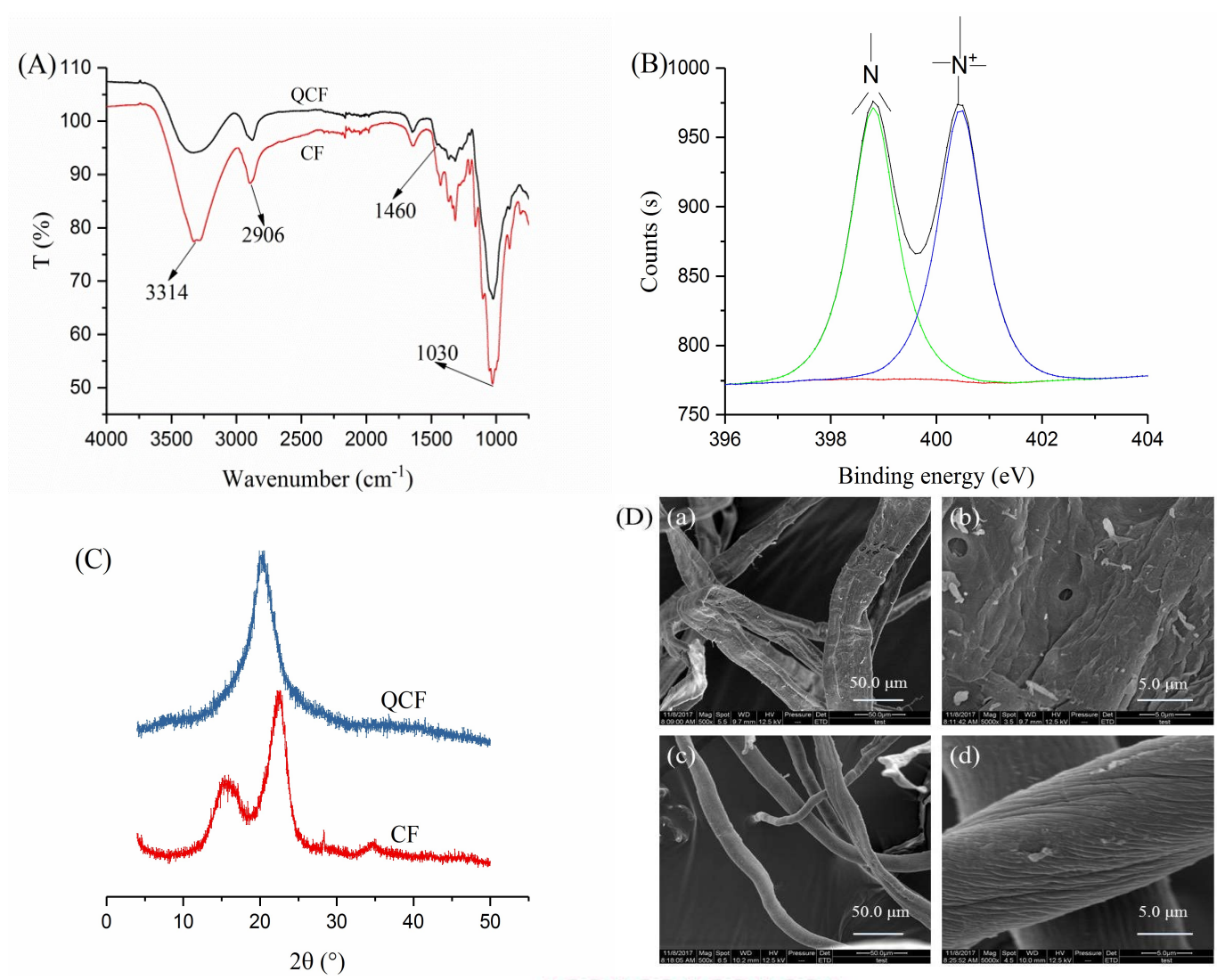

(E)

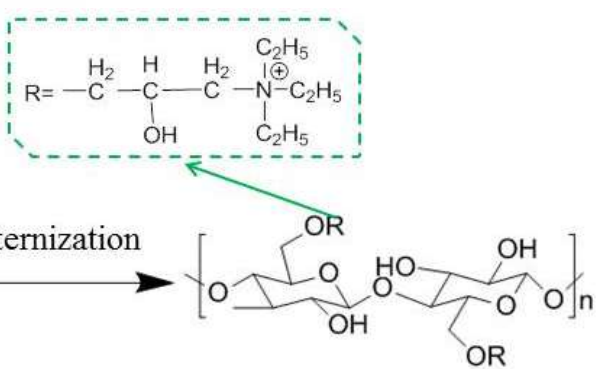

Figure 2. (A) FTIR spectra of CF and QCF; (B) N1s spectrum of QCF; (C) XRD patterns of CF and QCF; (D) SEM photographs of CF $((\mathbf{a}) \times 500,(\mathbf{b}) \times 5000)$ and QCF $((\mathbf{c}) \times 500,(\mathbf{d}) \times 5000)$; and $(\mathrm{E})$ the chemical structure of QCF.

Figure $2 \mathrm{C}$ exhibits the XRD patterns of the $\mathrm{CF}$ and the QCF. The CF showed a typical cellulose I structure including peaks at $15.62^{\circ}, 22.62^{\circ}$ and $34.08^{\circ}$. Compared with the $\mathrm{CF}$, the characteristic peaks disappeared and a new peak at $20.32^{\circ}$ appeared in the XRD pattern of the QCF, which indicated a typical cellulose II structure, and showed that intermolecular and intramolecular hydrogen bonds of CF were destroyed during quaternization. The SEM photographs of the CF and the QCF are exhibited in Figure 2D. The CF fibers [Figure $2(\mathrm{Da}, \mathrm{Db})]$ were ribbon-like with impurities, showing a rough and 
wrinkled surface. After quaternization, the impurities disappeared and the surface was uniformly ridged [Figure $2(\mathrm{Dc}, \mathrm{Dd})]$. The chemical structure of the QCF can be described as shown in Figure 2E based on the above analysis.

\subsection{Effect of Contact Time}

The effects of the adsorption time on the BTB adsorption onto the QCF at 303.15, 313.15 and 323.15 K are exhibited in Figure 3a. The entire adsorption process can be distributed into three sections: a rapid adsorption phase (0 60 $\mathrm{min})$ which shows a liner growth trend; a slow adsorption phase (60 90 $\mathrm{min}$ ) and an equilibrium stage from 120 to $240 \mathrm{~min}$. The increase in the adsorption rate during the primary stage may have resulted from the higher force and sufficient availability of active sites for BTB to transfer to the QCF. The amount of active sites decreased rapidly with an increase in contact time, which resulted in a reduction in the adsorption rate. The equilibrium adsorption capability increased as the temperature increased, which demonstrated that a higher temperature benefited the BTB adsorption on the QCF.
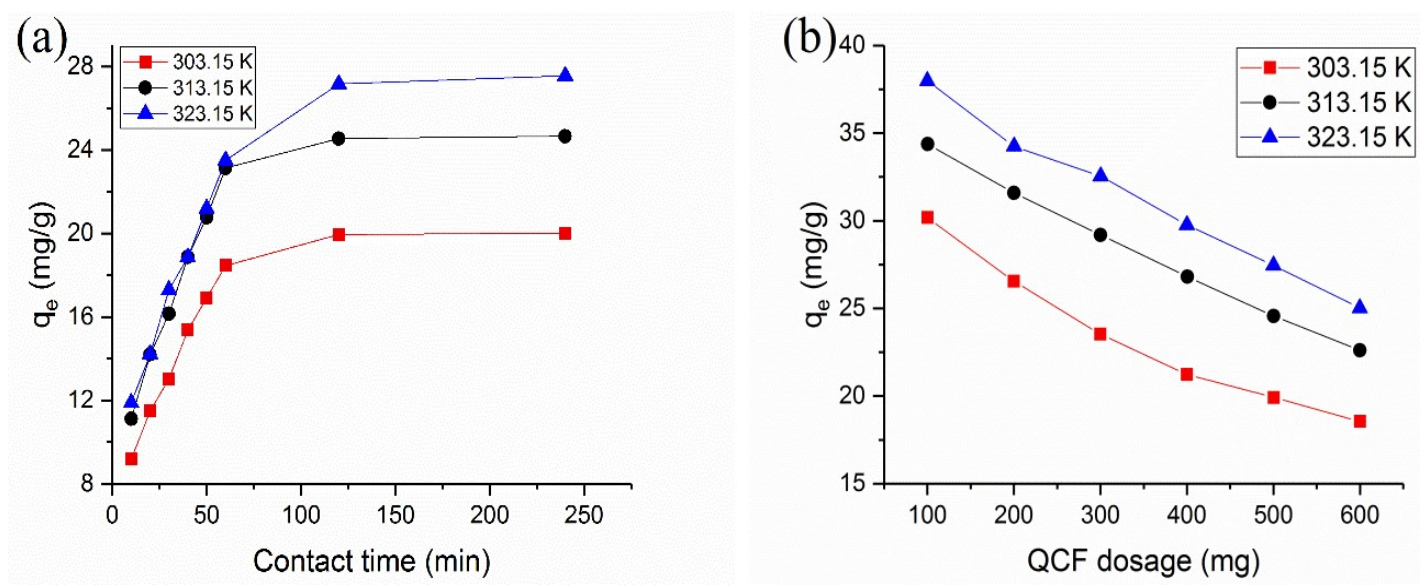

Figure 3. Effects of (a) contact time and (b) QCF dosage on the BTB adsorption onto QCF.

\subsection{Effect of Adsorbent Dosage}

As can be seen from Figure $3 b$, the equilibrium adsorption capacity decreased with an increase of the QCF dosage, showing a liner reduction. The increased quality of the QCF could provide more active sites for BTB adsorption, and the adsorption reached saturation with a small amount of the QCF. The equilibrium adsorption capacity gradually increased as the temperature increased, which demonstrated that a high temperature promoted the adsorption.

\subsection{Adsorption Kinetics}

Pseudo-first-order [40] and pseudo-second-order [41] models were applied to explore the adsorption process. The fitted curves and parameters of the two models are shown in Figure 4 and Table 1 . The linearity of the pseudo-first-order model was poor, and the difference between the calculated $\mathrm{q}_{\mathrm{e}}\left(\mathrm{q}_{\mathrm{e}, \mathrm{cal}}\right)$ and experimental $\mathrm{q}_{\mathrm{e}}\left(\mathrm{q}_{\mathrm{e}, \exp }\right)$ values was large. This disparity showed that the adsorption of BTB on the QCF cannot be accurately described with the pseudo-first-order kinetic model. The $\mathrm{R}^{2}$ of the pseudo-second-order at three experimental temperatures were $0.998,0.997$ and 0.997, which indicated excellent linearity. The difference between the calculated $\mathrm{q}_{\mathrm{e}}\left(\mathrm{q}_{\mathrm{e}, \mathrm{cal}}\right)$ and the experimental $\mathrm{q}_{\mathrm{e}}\left(\mathrm{q}_{\mathrm{e}, \mathrm{exp}}\right)$ is smaller. Therefore, the pseudo-second-order can describe the adsorption process well. 

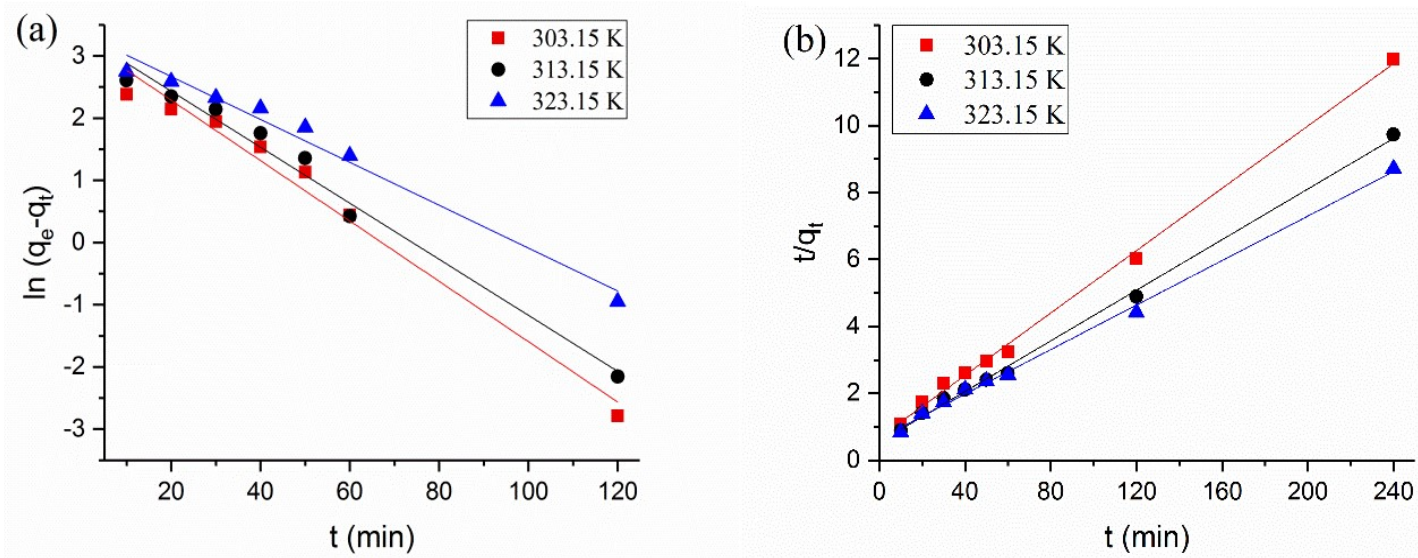

Figure 4. Fitting curves of (a) pseudo-first-order; and (b) pseudo-second-order.

Table 1. Kinetic parameters of the adsorption BTB onto QCF.

\begin{tabular}{cccc}
\hline \multirow{2}{*}{ Parameters } & \multicolumn{3}{c}{ Temperature (K) } \\
\cline { 2 - 4 } & $\mathbf{3 0 3 . 1 5}$ & $\mathbf{3 1 3 . 1 5}$ & $\mathbf{3 2 3 . 1 5}$ \\
\hline $\mathrm{q}_{\mathrm{e}, \text { exp }}(\mathrm{mg} / \mathrm{g})$ & 21.016 & 24.661 & 27.549 \\
Pseudo-first-order & & & \\
$\mathrm{K}_{1}\left(\mathrm{~min}^{-1}\right)$ & 0.034 & 0.045 & 0.049 \\
$\mathrm{q}_{\mathrm{e}, \mathrm{cal}}(\mathrm{mg} / \mathrm{g})$ & 28.703 & 28.022 & 25.972 \\
$\mathrm{R}^{2}$ & 0.975 & 0.979 & 0.975 \\
Pseudo-second-order $_{\mathrm{K}}$ & & & \\
$\mathrm{K}_{2}\left(\mathrm{mg} \cdot \mathrm{g}^{-1} \cdot \mathrm{min}^{-1}\right)$ & 0.0032 & 0.0026 & 0.0017 \\
$\mathrm{q}_{\mathrm{e}, \mathrm{cal}}\left(\mathrm{mg}^{\mathrm{g}}\right)$ & 21.459 & 26.316 & 28.303 \\
$\mathrm{R}^{2}$ & 0.998 & 0.997 & 0.997 \\
Ea $\left(\mathrm{kJ} \cdot \mathrm{mol}^{-1}\right)$ & & 52.89 & \\
\hline
\end{tabular}

The activation energy of adsorption was calculated from the Arrhenius equation. In general, the values of the activation energy can be applied to distinguish whether the adsorption is physically (4 40 kJ/mol) or chemically controlled (higher than $40 \mathrm{~kJ} / \mathrm{mol}$ ) [42]. The activation energy for the BTB adsorption onto the QCF was $52.89 \mathrm{~kJ} / \mathrm{mol}$, which proved that the BTB adsorption was chemically controlled. The interaction between the QCF and BTB was very strong and the strategy for anchoring BTB on cationic cellulose was successful.

\subsection{Adsorption Isotherms}

Adsorption isotherms can tell us how the adsorption conducts and help us analyze the interaction between the adsorbate and the adsorbent $[43,44]$. Langmuir, Freundlich and Temkin isotherms were tested to investigate the best description for the BTB sorption equilibrium, and to help understand the adsorption mechanism. The fitting curves and parameters of each isotherm are listed in Figure 5 and Table 2. The parameters of the Langmuir isotherm showed that the values of $\mathrm{q}_{\mathrm{m}}$ and $\mathrm{K}_{\mathrm{L}}$ are negative, which indicated that the adsorption of BTB onto the QCF did not fit the Langmuir model well. However, the values of the correlation coefficient $\left(R^{2}\right)$ were higher than 0.96 for the Freundlich and Temkin isotherm models, which described the BTB adsorption onto the QCF well.

\subsection{Analyses of IS-pH-SCF}

The SEM photographs in Figure 6A show that the surface of IS-pH-SCF was similar to that of the QCF due to only $\sim 4.0 \%$ of BTB being adsorbed on the surface, which resulted in little effect. As shown in Figure 6B, the FTIR spectra of the QCF and IS-pH-SCF were very similar. For the QCF, the band at $\sim 3335 \mathrm{~cm}^{-1}$ was ascribed to the $\mathrm{O}-\mathrm{H}$. The band at $\sim 2880 \mathrm{~cm}^{-1}$ was attributed to the $\mathrm{C}-\mathrm{H}$ 
for $-\mathrm{CH}_{2}-$ groups. The bands at $\sim 1158,1098,1057$, and $1030 \mathrm{~cm}^{-1}$ corresponded to the $\mathrm{C}-\mathrm{O}-\mathrm{C}$ from the glycosidic bonds of the cellulose molecule. After adsorption, the strength of the $\mathrm{O}-\mathrm{H}$ band was enhanced and moved to a low wavenumber. The band at $2880 \mathrm{~cm}^{-1}$ became stronger, which indicated that the new $-\mathrm{CH}_{2}-$ groups had been introduced into the QCF structure. A new peak at $\sim 1330 \mathrm{~cm}^{-1}$ indicated the $\mathrm{S}=\mathrm{O}$ stretching, and showed that the BTB had been included in the IS-pH-SCF structure. From the adsorption experiments, the maximum adsorption capacity was $38 \mathrm{mg} / \mathrm{g}$ for $1000 \mathrm{mg} / \mathrm{L}$ of $\mathrm{BTB} / \mathrm{NaOH}$ solution and a dosage of $100 \mathrm{mg}$ for $4 \mathrm{~h}$. The BTB content of IS-pH-SCF is $0.038 \%(w / w)$.
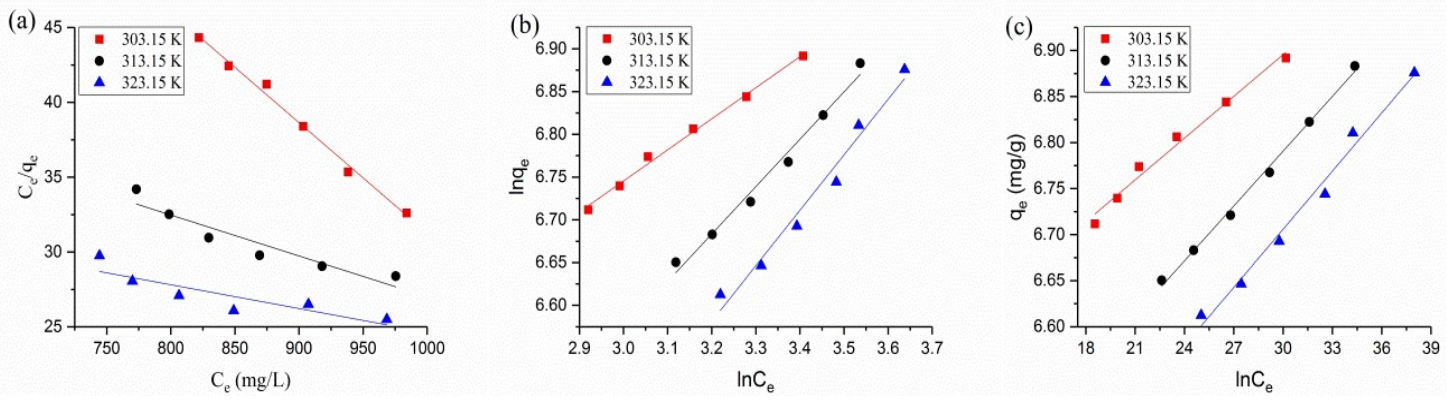

Figure 5. Fitting curves of (a) Langmuir; (b) Freundlich; and (c) Temkin isotherms.

Table 2. Isotherm parameters of the adsorption BTB onto QCF.

\begin{tabular}{|c|c|c|c|}
\hline \multirow{2}{*}{ Parameters } & \multicolumn{3}{|c|}{ Temperature (K) } \\
\hline & 303.15 & 313.15 & 323.15 \\
\hline \multicolumn{4}{|l|}{ Langmuir } \\
\hline $\mathrm{K}_{\mathrm{L}}\left(\mathrm{L} \cdot \mathrm{mg}^{-1} \times 10^{-4}\right)$ & -7.039 & -0.162 & -3.922 \\
\hline $\mathrm{q}_{\mathrm{m}}(\mathrm{mg} / \mathrm{g})$ & -13.514 & -37.037 & -62.893 \\
\hline$R^{2}$ & 0.992 & 0.892 & 0.770 \\
\hline Freundlich & & & \\
\hline$\underset{\left(\left[m g^{1-(1 / n)} /\left(g \cdot L^{-1 / n}\right]\right)\right.}{K_{2}}$ & 286.00 & 135.64 & 90.56 \\
\hline $1 / \mathrm{n}$ & 0.363 & 0.554 & 0.649 \\
\hline $\mathrm{R}^{2}$ & 0.995 & 0.981 & 0.967 \\
\hline \multicolumn{4}{|l|}{ Temkin } \\
\hline A & 6.442 & 6.195 & 6.075 \\
\hline B & 0.015 & 0.020 & 0.021 \\
\hline$R^{2}$ & 0.980 & 0.995 & 0.982 \\
\hline
\end{tabular}

(A)
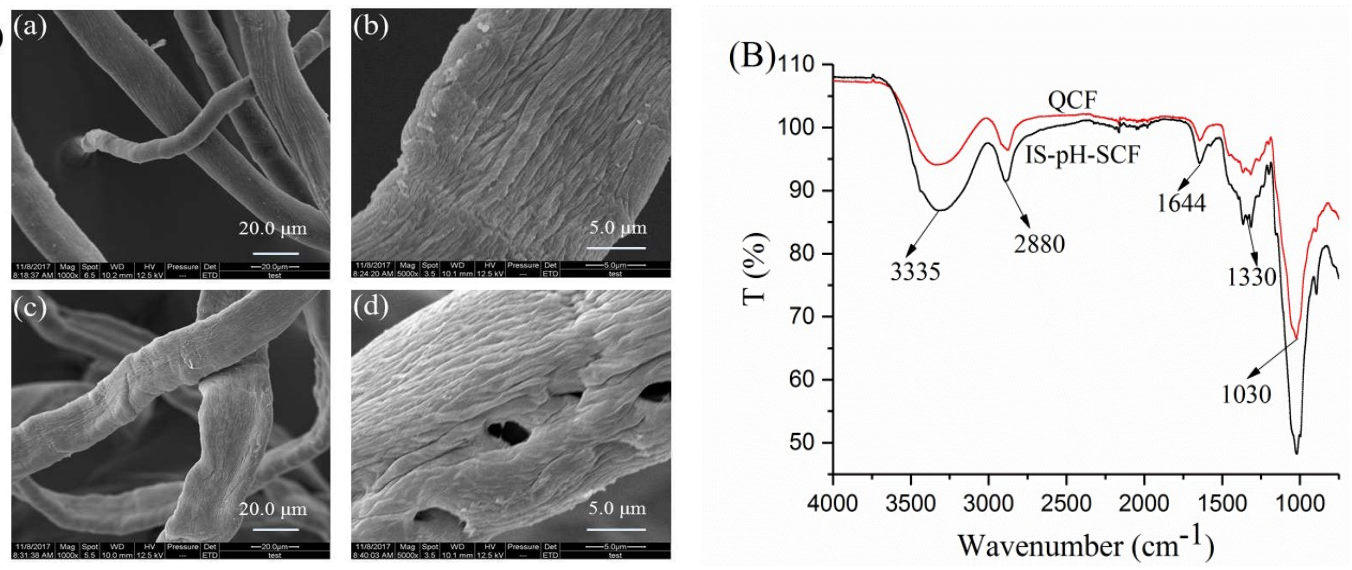

Figure 6. (A) SEM of QCF $((\mathbf{a}) \times 1000,(\mathbf{b}) \times 5000))$ and IS-pH-SCF $((\mathbf{c}) \times 1000,(\mathbf{d}) \times 5000)$; (B) FTIR spectra of QCF and IS-pH-SCF. 


\section{7. $p H$ Response of IS- $p H-S C F$}

The response of the IS-pH-SCF at different $\mathrm{pH}$ values was shown in Table 3. The IS-pH-SCF color changed obviously when exposed to buffer solutions with a $\mathrm{pH}$ range from 4 to 8 . The IS-pH-SCF was orange at $\mathrm{pH} 4$, reddish-brown at $\mathrm{pH} 5$, yellow-green at $\mathrm{pH} 6$, purplish-blue at $\mathrm{pH} 7$, and dark-blue at $\mathrm{pH}$ 8. The buffer solution also seems to exhibit a corresponding color; the reason is that the IS-pH-SCF felt was made of short fibers $(\sim 150 \mu \mathrm{m})$ whose intermolecular interactions are particularly weak and which will disperse once immersed in a buffer solution. The color parameters of the IS-pH-SCF were also tested for responses in different $\mathrm{pH}$ buffer solutions, as shown in Table 3. The b value of the IS-pH-SCF decreased rapidly from 72.510 to -0.152 , which suggested that the color changed from yellow to blue. The values of a decreased significantly with an increase in $\mathrm{pH}$, which indicated that the IS-pH-SCF changed from red to green. The L values exhibited a decreasing tend, which showed that the lightness of IS-pH-SCF decreased gradually with an increase in $\mathrm{pH}$. These results agreed with the photographs of the IS-pH-SCF in Table 3. In general, color changes could be detected with the naked eye when the total color change $(\Delta \mathrm{E})$ exceeded 5 [45]. The $\Delta \mathrm{E}$ at each $\mathrm{pH}$ exceeded 5 , which showed that the IS-pH-SCF was highly sensitive to $\mathrm{pH}$ values from 4 to 8 .

Table 3. $\mathrm{pH}$ response of IS-pH-SCF under $\mathrm{pH}$ from 4 to 8.

\begin{tabular}{cccccc}
\hline $\mathbf{p H}$ & $\mathbf{L}$ & $\mathbf{a}$ & $\mathbf{b}$ & $\Delta \mathrm{E}$ & Photos \\
\hline 4 & $42.228 \pm 1.569$ & $48.675 \pm 2.211$ & $72.510 \pm 2.716$ & $104.503 \pm 2.026$ & \\
\hline 5 & $28.148 \pm 0.614$ & $33.510 \pm 0.514$ & $47.930 \pm 1.067$ & $92.277 \pm 0.264$ & \\
\hline 6 & $0.390 \pm 0.064$ & $2.230 \pm 0.486$ & $0.398 \pm 0.097$ & $85.055 \pm 0.052$ & \\
\hline 7 & $0.142 \pm 0.004$ & $0.470 \pm 0.041$ & $-0.128 \pm 0.074$ & $74.276 \pm 0.004$ & \\
\hline & & & & \\
\hline
\end{tabular}

\subsection{Release of BTB from IS- $p H-S C F$}

The release of BTB from IS-pH-SCF in distilled water and dropping acid or alkaline solutions was investigated. As shown in Figure 7a, the color of the IS-pH-SCF did not change and the resulting distilled water after centrifugation was still colorless after the IS-pH-SCF was soaked for $24 \mathrm{~h}$, which demonstrated that no BTB escaped from the fibers into distilled water. The IS-pH-SCF turned orange after making contact with the $\mathrm{HCl}$ solution. Subsequently, the color returned to the initial dark-blue immediately after a $\mathrm{NaOH}$ solution was dropped on the color-changed part. The filter paper under the IS-pH-SCF was colorless, as shown in Figure 7b, which further indicated that no BTB was released from the IS-pH-SCF. The results show that BTB successfully anchored on cationic cellulose fibers and that the fibers loading BTB are in-situ sensitive to $\mathrm{pH}$ change. 
(a)
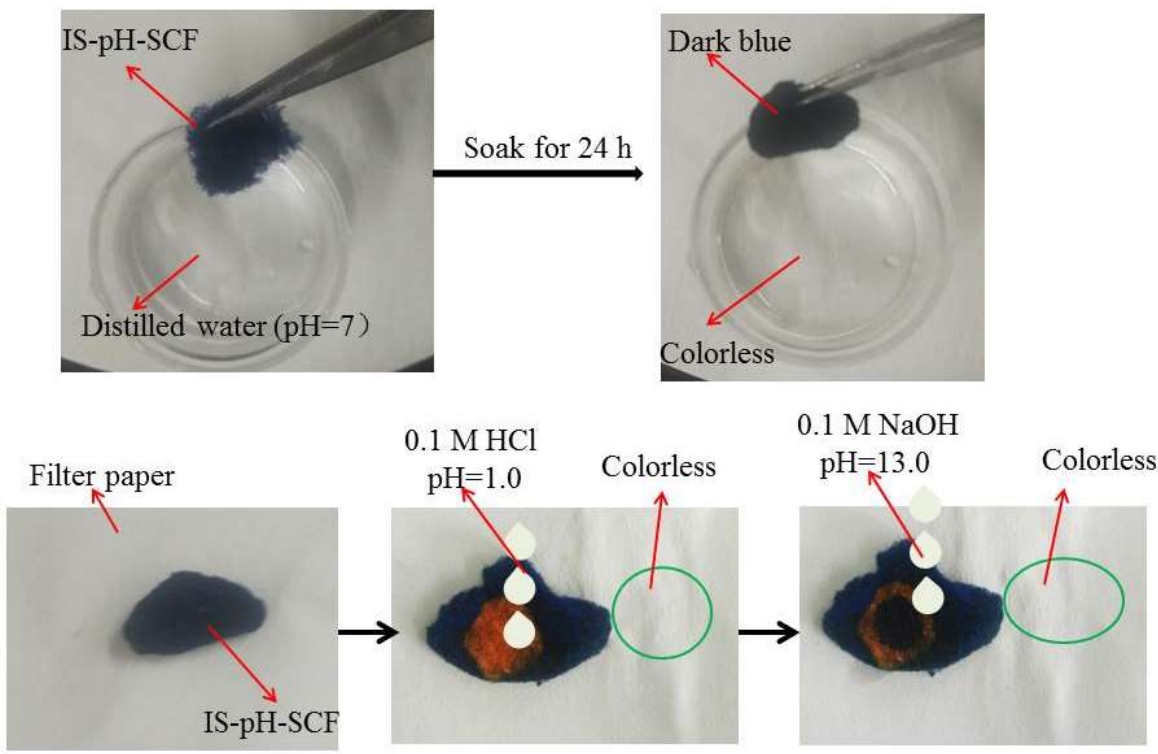

Figure 7. Release tests (a) in distilled water and (b) dropping acid or alkaline solutions.

\section{Conclusions}

IS-pH-SCF was prepared by anchoring BTB molecules on a cationic cellulose fiber through adsorption. It was proven by FTIR and XPS analyses that the cationic modification by grafting hydroxypropyltriethylamine groups onto CFs was completed. SEM observations showed that the QCF surface became uniformly wrinkled. QCF was used as an adsorbent to anchor BTB in the alkaline solution. A higher temperature favored BTB adsorption onto the QCF. The maximum adsorption capacity was $38 \mathrm{mg} / \mathrm{g}$ for $1000 \mathrm{mg} / \mathrm{L}$ of $\mathrm{BTB} / \mathrm{NaOH}$ solution and a dosage of $100 \mathrm{mg}$ for $4 \mathrm{~h}$. The adsorption of BTB on the QCF followed pseudo-second-order kinetics, and Freundlich and Temkin isotherms. The IS-pH-SCF exhibited a different color for each $\mathrm{pH}$ value from 4 to 8 . Simultaneously, the BTB was not released during the $\mathrm{pH}$ response, which conformed that the BTB was anchored firmly on the cationic cellulose fiber. This study provides a new path for fabricating a $\mathrm{pH}$-sensitive fiber that could be used to monitor the freshness of food without any pollution.

Author Contributions: L.W. and T.L. conceived and designed the experiments; L.C., T.L. and X.Z. (Xipeng Zhang) performed the experiments; L.W., L.C., W.L., J.L. and X.Z. (Xianxu Zhan) analyzed the data; L.C. wrote the paper and L.W. proofread the technical content.

Funding: National Natural Science Foundation of China (31770618), the Fundamental Research Funds for Central Universities (2572017AB11) and the Key Research and Development Program of Zhejiang province (2017C01117).

Acknowledgments: This work was supported by the National Natural Science Foundation of China (31770618), the Fundamental Research Funds for Central Universities (2572017AB11) and the Key Research and Development Program of Zhejiang province (2017C01117).

Conflicts of Interest: The authors declare no conflict of interest.

\section{References}

1. Hua, M.Z.; Feng, S.; Wang, S.; Lu, X. Rapid detection and quantification of 2,4-dichlorophenoxyacetic acid in milk using molecularly imprinted polymers-surface-enhanced raman spectroscopy. Food Chem. 2018, 258, 254-259. [CrossRef] [PubMed]

2. Poyatos-Racionero, E.; Ros-Lis, J.V.; Vivancos, J.-L.; Martínez-Máñez, R. Recent advances on intelligent packaging as tools to reduce food waste. J. Clean. Prod. 2018, 172, 3398-3409. [CrossRef]

3. Lee, G.-Y.; Lee, S.; Shin, H.-S. Evaluation of gas freshness indicator for determination of skate (Raja kenojei) quality during storage. Food Sci. Biotechnol. 2016, 25, 1497-1500. [CrossRef] 
4. Tang, Y.; Liu, Y.; Cao, A. Strategy for sensor based on fluorescence emission red shift of conjugated polymers: Applications in pH response and enzyme activity detection. Anal. Chem. 2013, 85, 825-830. [CrossRef] [PubMed]

5. Del Ben, F.; Turetta, M.; Celetti, G.; Piruska, A.; Bulfoni, M.; Cesselli, D.; Huck, W.T.S.; Scoles, G. A method for detecting circulating tumor cells based on the measurement of single-cell metabolism in droplet-based microfluidics. Angew. Chem. 2016, 128, 8723-8726. [CrossRef]

6. Peng, H.S.; Stolwijk, J.A.; Sun, L.N.; Wegener, J.; Wolfbeis, O.S. A nanogel for ratiometric fluorescent sensing of intracellular pH values. Angew. Chem. Int. Ed. Engl. 2010, 49, 4246-4249. [CrossRef] [PubMed]

7. Swietach, P.; Vaughan-Jones, R.D.; Harris, A.L.; Hulikova, A. The chemistry, physiology and pathology of pH in cancer. Philos. Trans. R. Soc. Lond. B. Biol. Sci. 2014, 369, 20130099. [CrossRef] [PubMed]

8. Huang, W.; Takebayashi, N.; Qi, Y.; Hickerson, M.J. MTML-msBayes: Approximate Bayesian comparative phylogeographic inference from multiple taxa and multiple loci with rate heterogeneity. BMC Bioinform. 2011, 12, 1. [CrossRef] [PubMed]

9. Wencel, D.; Abel, T.; McDonagh, C. Optical chemical pH sensors. Anal. Chem. 2014, 86, 15-29. [CrossRef] [PubMed]

10. Chen, Q.; Huang, F.; Cai, G.; Wang, M.; Lin, J. An optical biosensor using immunomagnetic separation, urease catalysis and $\mathrm{pH}$ indication for rapid and sensitive detection of Listeria monocytogenes. Sens. Actuators B Chem. 2018, 258, 447-453. [CrossRef]

11. Kuswandi, B.; Wicaksono, Y.; Abdullah, A.; Heng, L.Y.; Ahmad, M. Smart packaging: Sensors for monitoring of food quality and safety. Sens. Instrum. Food Qual. Saf. 2011, 5, 137-146. [CrossRef]

12. Yam, K.L. Intelligent packaging to enhance food safety and quality. Emerg. Food Packag. Technol. 2012, 137-152.

13. O'Grady, M.N.; Kerry, J.P. Smart packaging technologies and their application in conventional meat packaging systems. In Meat Biotechnology; Springer: New York, NY, USA, 2008; pp. 425-451.

14. Ma, Q.; Ren, Y.; Gu, Z.; Wang, L. Developing an intelligent film containing Vitis amurensis husk extracts: The effects of $\mathrm{pH}$ value of the film-forming solution. J. Clean. Prod. 2017, 166, 851-859. [CrossRef]

15. Nopwinyuwong, A.; Trevanich, S.; Suppakul, P. Development of a novel colorimetric indicator label for monitoring freshness of intermediate-moisture dessert spoilage. Talanta 2010, 81, 1126-1132. [CrossRef] [PubMed]

16. Zhang, X.; Lu, S.; Chen, X. A visual $\mathrm{pH}$ sensing film using natural dyes from Bauhinia blakeana Dunn. Sens. Actuators B Chem. 2014, 198, 268-273. [CrossRef]

17. Prietto, L.; Mirapalhete, T.C.; Pinto, V.Z.; Hoffmann, J.F.; Vanier, N.L.; Lim, L.-T.; Guerra Dias, A.R.; da Rosa Zavareze, E. pH-sensitive films containing anthocyanins extracted from black bean seed coat and red cabbage. LWT Food Sci. Technol. 2017, 80, 492-500. [CrossRef]

18. Yoshida, C.M.P.; Maciel, V.B.V.; Mendonça, M.E.D.; Franco, T.T. Chitosan biobased and intelligent films: Monitoring $\mathrm{pH}$ variations. LWT Food Sci. Technol. 2014, 55, 83-89. [CrossRef]

19. Ma, Q.; Liang, T.; Cao, L.; Wang, L. Intelligent poly (vinyl alcohol)-chitosan nanoparticles-mulberry extracts films capable of monitoring pH variations. Int. J. Biol. Macromol. 2018, 108, 576-584. [CrossRef] [PubMed]

20. Gutierrez, T.J.; Guzman, R.; Medina Jaramillo, C.; Fama, L. Effect of beet flour on films made from biological macromolecules: Native and modified plantain flour. Int. J. Biol. Macromol. 2016, 82, 395-403. [CrossRef] [PubMed]

21. Gutiérrez, T.J.; Ponce, A.G.; Alvarez, V.A. Nano-clays from natural and modified montmorillonite with and without added blueberry extract for active and intelligent food nanopackaging materials. Mater. Chem. Phys. 2017, 194, 283-292. [CrossRef]

22. Chen, L.X. Discoloration property for $\mathrm{pH}$-sensitivity of fabric dyed by turmeric. J. Text. Res. 2016, 38, 5 .

23. Liu, X.; Zhang, S.Q.; Wei, X.; Yang, T.; Chen, M.L.; Wang, J.H. A novel "modularized" optical sensor for $\mathrm{pH}$ monitoring in biological matrixes. Biosens. Bioelectron. 2018, 109, 150-155. [CrossRef] [PubMed]

24. Rukchon, C.; Nopwinyuwong, A.; Trevanich, S.; Jinkarn, T.; Suppakul, P. Development of a food spoilage indicator for monitoring freshness of skinless chicken breast. Talanta 2014, 130, 547-554. [CrossRef] [PubMed]

25. Gao, L.; Yang, X.; Shu, Y.; Chen, X.; Wang, J. Ionic liquid-based slab optical waveguide sensor for the detection of ammonia in human breath. J. Colloid Interface Sci. 2018, 512, 819-825. [CrossRef] [PubMed]

26. Xu, Q.; Chen, C.; Rosswurm, K.; Yao, T.; Janaswamy, S. A facile route to prepare cellulose-based films. Carbohydr. Polym. 2016, 149, 274-281. [CrossRef] [PubMed] 
27. Xiong, J.; Yu, S.; Zhu, H.; Wang, S.; Chen, Y.; Liu, S. Dissolution and structure change of bagasse cellulose in zinc chloride solution. BioResources 2016, 11, 3813-3824. [CrossRef]

28. Hu, D.; Wang, L. Adsorption of amoxicillin onto quaternized cellulose from flax noil: Kinetic, equilibrium and thermodynamic study. J. Taiwan Inst. Chem. E 2016, 64, 227-234. [CrossRef]

29. Ho, Y.S.; McKay, G. Sorption of dye from aqueous solution by peat. Chem. Eng. J. 1998, 70, 115-124. [CrossRef]

30. Changmai, M.; Banerjee, P.; Nahar, K.; Purkait, M.K. A novel adsorbent from carrot, tomato and polyethylene terephthalate waste as a potential adsorbent for Co (II) from aqueous solution: Kinetic and equilibrium studies. J. Environ. Chem. Eng. 2018, 6, 246-257. [CrossRef]

31. Cheah, W.; Hosseini, S.; Khan, M.A.; Chuah, T.G.; Choong, T.S.Y. Acid modified carbon coated monolith for methyl orange adsorption. Chem. Eng. J. 2013, 215, 747-754. [CrossRef]

32. Namasivayam, C.; Kavitha, D. Removal of Congo Red from water by adsorption onto activated carbon prepared from coir pith, an agricultural solid waste. Dyes Pigment. 2002, 54, 47-58. [CrossRef]

33. Sprynskyy, M.; Kowalkowski, T.; Tutu, H.; Cukrowska, E.M.; Buszewski, B. Ionic liquid modified diatomite as a new effective adsorbent for uranium ions removal from aqueous solution. Colloids Surf. A Physicochem. Eng. Asp. 2015, 465, 159-167. [CrossRef]

34. Zavareh, S.; Farrokhzad, Z.; Darvishi, F. Modification of zeolite 4A for use as an adsorbent for glyphosate and as an antibacterial agent for water. Ecotoxicol. Environ. Saf. 2018, 155, 1-8. [CrossRef] [PubMed]

35. Elwakeel, K.Z.; Elgarahy, A.M.; Mohammad, S.H. Use of beach bivalve shells located at port said coast (Egypt) as a green approach for methylene blue removal. J. Environ. Chem. Eng. 2017, 5, 578-587. [CrossRef]

36. Zhang, X.; Tan, J.; Wei, X.; Wang, L. Removal of remazol turquoise blue G-133 from aqueous solution using modified waste newspaper fiber. Carbohydr. Polym. 2013, 92, 1497-1502. [CrossRef] [PubMed]

37. Cao, W.; Dang, Z.; Zhou, X.-Q.; Yi, X.-Y.; Wu, P.-X.; Zhu, N.-W.; Lu, G.-N. Removal of sulphate from aqueous solution using modified rice straw: Preparation, characterization and adsorption performance. Carbohydr. Polym. 2011, 85, 571-577. [CrossRef]

38. Tastet, D.; Save, M.; Charrier, F.; Charrier, B.; Ledeuil, J.-B.; Dupin, J.-C.; Billon, L. Functional biohybrid materials synthesized via surface-initiated MADIX/RAFT polymerization from renewable natural wood fiber: Grafting of polymer as non leaching preservative. Polymer 2011, 52, 606-616. [CrossRef]

39. Hu, D.; Wang, P.; Li, J.; Wang, L. Functionalization of microcrystalline cellulose with $\mathrm{N}, \mathrm{N}$-dimethyldodecylamine for the removal of Congo Red dye from an aqueous solution. BioResources 2014, 9, 5951-5962. [CrossRef]

40. Ho, Y.S.; McKay, G. Kinetic models for the sorption of dye from aqueous solution by wood. Process Saf. Environ. Prot. 1998, 76, 183-191. [CrossRef]

41. Ho, Y.S.; McKay, G. Pseudo-second order model for sorption processes. Process Biochem. 1999, 34, 451-465. [CrossRef]

42. Konicki, W.; Sibera, D.; Mijowska, E.; Lendzion-Bielun, Z.; Narkiewicz, U. Equilibrium and kinetic studies on acid dye Acid Red 88 adsorption by magnetic $\mathrm{ZnFe}_{2} \mathrm{O}_{4}$ spinel ferrite nanoparticles. J. Colloid Interface Sci. 2013, 398, 152-160. [CrossRef] [PubMed]

43. Elwakeel, K.Z.; El-Bindary, A.A.; El-Sonbati, A.Z.; Hawas, A.R. Adsorption of toxic acidic dye from aqueous solution onto diethylenetriamine functionalized magnetic glycidyl methacrylate- $N, N^{\prime}$-methylenebisacrylamide. RSC Adv. 2016, 6, 3350-3361. [CrossRef]

44. Elwakeel, K.Z.; El-Bindary, A.A.; Ismail, A.; Morshidy, A.M. Sorptive removal of Remazol Brilliant Blue $\mathrm{R}$ from aqueous solution by diethylenetriamine functionalized magnetic macro-reticular hybrid material. RSC Adv. 2016, 6, 22395-22410. [CrossRef]

45. Pourjavaher, S.; Almasi, H.; Meshkini, S.; Pirsa, S.; Parandi, E. Development of a colorimetric $\mathrm{pH}$ indicator based on bacterial cellulose nanofibers and red cabbage (Brassica oleraceae) extract. Carbohydr. Polym. 2017, 156, 193-201. [CrossRef] [PubMed]

(c) 2018 by the authors. Licensee MDPI, Basel, Switzerland. This article is an open access article distributed under the terms and conditions of the Creative Commons Attribution (CC BY) license (http:/ / creativecommons.org/licenses/by/4.0/). 